\title{
Pengembangan Tanaman Herbal Sebagai Destinasi Wisata di Desa Catur, Kintamani, Bali
}

\section{Development of Herbal Plants as a Tourist Destination in Catur Village, Kintamani, Bali}

\author{
${ }^{1}$ Dermawan Waruwu, 2Ni Made Diana Erfiani, ${ }^{3}$ I Putu Darmawijaya, \\ ${ }^{4}$ Natalia Sri Endah Kurniawati
}

\begin{abstract}
${ }^{1}$ Program Studi Psikologi, Fakultas Ilmu Kesehatan, Sains, dan Teknologi, Universitas
Dhyana Pura, Provinsi Bali

2Program Studi Sastra Inggris, Fakultas Ekonomika dan Humaniora, Universitas Dhyana Pura, Provinsi Bali

${ }^{3}$ Program Studi Fisioterapi, Fakultas Ilmu Kesehatan, Sains, dan Teknologi, Universitas Dhyana Pura, Provinsi Bali

${ }^{4}$ Program Studi Manajemen Pemasaran, Fakultas Ekonomika dan Humaniora, Universitas Dhyana Pura, Provinsi Bali
\end{abstract}

Korespondensi: D. Waruwu, dermawanwaruwu@undhirabali.ac.id

Naskah Diterima: 18 September 2019. Disetujui: 21 Januari 2020. Disetujui Publikasi: 22 Januari 2020

\begin{abstract}
The people of Catur Village are classified as less prosperous economically but have the potential for natural products and cultural uniqueness. Quite a lot of natural products in this area in the form of coffee, oranges, lemongrass, sweet potatoes, ginger, turmeric, and so on. These natural products are classified as herbs that are beneficial to health. Natural products and cultural uniqueness have not been developed into tourist attractions because people lack knowledge and skills. The Partner Village Development Program (PPDM) is a solution to the problems faced by the community. The PPDM implementation team provides training and assistance to the Women Farmers Group (KWT) and Tourism Awareness Group (Pokdarwis). The purpose of implementing PPDM in Catur Village is that KWT and Pokdarwis have the knowledge and skills in developing their natural and cultural potential. This training and assistance resulted in three things: First, KWT and Pokdarwis members were able to cultivate herbal plants in their yard or garden; Second, KWT and Pokdarwis members are able to make coffee perfume and process coffee waste into cascara tea and coffee leaf tea; Third, KWT and Pokdarwis members are able to organize tourist attractions and make trekking paths in the tourist area. The development and promotion of this tourist village use technology and social media such as Facebook, Youtube, and other online media. Thus, the tourist area in Catur Village, Kintamani Bali becomes an educational and contemporary tourism destination based on herbs.
\end{abstract}

Keywords: Herbal plants, herbal tourism, technology, Catur Village, Kintamani Bali.

\begin{abstract}
Abstrak: Masyarakat Desa Catur tergolong kurang sejahtera secara ekonomi, namun memiliki potensi hasil alam dan keunikan budaya. Hasil alam cukup banyak di daerah ini berupa kopi, jeruk, sereh, bunga gumitir, ubi, jahe, kunyit, dan sebagainya. Hasil alam ini tergolong sebagai tanaman herbal yang bermanfaat bagi kesehatan. Hasil alam maupun keunikan budaya belum dikembangkan menjadi objek wisata karena masyarakatnya kurang pengetahuan serta keterampilan. Program Pengembangan Desa Mitra (PPDM) menjadi solusi terhadap masalah yang dihadapi oleh masyarakat tersebut. Tim pelaksana PPDM memberikan pelatihan dan pendampingan kepada Kelompok Wanita Tani (KWT) dan Kelompok Sadar Wisata (Pokdarwis). Tujuan pelaksanaan PPDM di Desa Catur adalah agar KWT dan Pokdarwis memiliki pengetahuan serta keterampilan dalam mengembangkan potensi alam maupun budayanya.
\end{abstract}


Pelatihan dan pendampingan ini menghasilkan tiga hal: Pertama, anggota KWT dan Pokdarwis mampu membudidayakan tanaman herbal di halaman rumah atau kebunnya; Kedua, anggota KWT dan Pokdarwis mampu membuat parfum kopi serta mengolah limbah kopi menjadi teh cerry kopi (cascara tea) dan teh daun kopi; Ketiga, anggota KWT dan Pokdarwis mampu menata objek wisata serta membuat jalur trekking di kawasan wisata tersebut. Pengembangan maupun promosi desa wisata ini menggunakan teknologi serta media sosial seperti facebook, youtube, dan media online lainnya. Dengan demikian, kawasan wisata di Desa Catur menjadi destinasi wisata edukasi dan kekinian yang berbasis pada herbal.

Kata Kunci: Tanaman herbal, wisata herbal, teknologi, Desa Catur, Bali.

\section{Pendahuluan}

Pelaksanaan Program Pengembangan Desa Mitra (PPDM) - Desa Wisata Herbal di Desa Catur, Kintamani, Kabupaten Bangli, Bali merupakan keinginan masyarakat untuk mengatasi masalah yang dihadapi selama ini. Masyarakat Desa Catur memiliki potensi wisata yang unik. Desa Catur memiliki keunggulan pada hasil alam berupa tanaman herbal, budaya, dan keindahan alamnya (Bangli DP \& KK, 2018). Sumber pencaharian masyarakat Desa Catur sebagian besar berasal dari hasil perkebunan dan peternakan, serta sebagian kecil bergerak di bidang perdagangan dan industri lainnya. Sumber pendapatan utama masyarakatnya adalah perkebunan kopi, daun jinten, jeruk, bunga gumitir, jahe, kunyit, sayursayuran, dan sebagainya. Kopi arabika Desa Catur sudah memiliki sertifikat IG (Indikasi Geografis) yang dapat digunakan sebagai jaminan kualitas produk kepada konsumen (Arnawa, 2014).

Tanaman kopi, daun jinten, jeruk, bunga gumitir, jahe, dan kunyit dikategorikan sebagai tanaman herbal yang berkhasiat bagi kesehatan. Kopi memiliki kandungan herbal alami yang terdapat pada daun, biji, dan buah, sehingga sekitar 80-90\% kopi dikonsumsi oleh orang dewasa setiap hari (AP, 2018). Daun jinten bermanfaat untuk menyembuhkan gangguan pernapasan, menjaga kesehatan kulit, mencegah kanker, menurunkan stress dan cemas, mengobati demam, mengatasi sindrom usus, mencegah sariawan, menjaga tekanan darah, dan sebagainya (Maressa, 2018). Pengembangan tanaman herbal di Desa Catur sangat tepat karena posisinya berada pada ketinggian 1.250 meter dari permukaan laut serta suhu sekitar $18-20^{\circ} \mathrm{C}$ (Desa Catur, 2011). Luas wilayahnya sekitar 7,56 $\mathrm{km} 2(746,00 \mathrm{Ha})$ yang merupakan lahan perkebunan dengan jumlah penduduk 2.079 jiwa atau sekitar 510 kepala keluarga (Bangli BPSK, 2017). Wilayah Desa Catur dikelola sebagai tegalan (perkebunan) sekitar $630 \mathrm{Ha}$ serta $320 \mathrm{Ha}$ dikelola sebagai perkebunan rakyat (Desa Catur, 2011).

Pengembangan potensi Desa Catur yang berbasis alam, perkebunan, dan budaya didukung oleh Bupati Bangli dengan menerbitkan Peraturan Bupati Nomor 4 Tahun 2018 yang menetapkan Desa Catur sebagai Desa Wisata. Menurut Bupati Bangli, Kabupaten Bangli pernah menjadi pusat perkembangan tanaman herbal di Bali yang dibuktikan dengan keberadaan mesin herbal berkapasitas besar di Puskesmas Pengotan. Pengembangan tanaman herbal di Desa Catur sejalan dengan program pemerintah melalui Kementerian Kesehatan yang melegalkan penggunaan produk herbal sebagai salah satu sarana pengobatan alternatif pada pasien. Peraturan Menteri Kesehatan Republik Indonesia Nomor 6 Tahun 2016 dijelaskan tentang Formularium Obat Herbal Asli Indonesia. Pengembangan tanaman herbal sesuai dengan hasil kesepakatan badan kesehatan dunia yaitu WHO promotes the use of traditional medicines in primary health care, particularly the use of herbal products. Pertemuan WHO itu menghasilkan kesepakatan untuk memperkuat Program Nasional dalam penggunaan Herbal Medicine bagi pelayanan kesehatan dasar masyarakat.

Pengembangan Desa Catur menjadi Desa Wisata Herbal didukung oleh masyarakat dengan membentuk Kelompok Wanita Tani (KWT) dan Kelompok Sadar 
Wisata (Pokdarwis). Keinginan pemerintah daerah dan masyarakat untuk mengembangkan potensi desanya ditindaklanjuti dengan meminta bantuan dan pendampingan dari dosen Universitas Dhyana Pura Bali melalui kegiatan PPDM. Masyarakat meminta pelatihan dan pendampingan tentang budidaya tanaman herbal, pembuatan dan pengemasan produk herbal, serta penataan desa menjadi kawasan wisata yang menarik bagi wisatawan. Jarak Desa Catur dari Universitas Dhyana Pura sekitar $53 \mathrm{~km}$ yang dapat ditempuh dengan kendaraan roda 2 atau roda 4 dalam waktu sekitar 90 menit.

Program Pengembangan Desa Mitra fokus pada upaya pengembangan tanaman herbal menjadi destinasi wisata yang didukung dengan keindahan alam dan keunikan budaya. Oleh sebab itu, anggota KWT dan Pokdarwis meminta pelatihan dan pendampingan kepada tim pelaksana PPDM agar mereka mampu mengelola hasil alamnya secara maksimal, sehingga menjadi destinasi wisata herbal. Keunggulan Desa Catur sebagai penghasil tanaman herbal di Bali diharapkan dapat menjadi daya tarik wisata baru bagi wisatawan domestik maupun mancanegara. Anggota Pokdarwis dilatih dan dibina untuk menata serta mengidentifikasi daya tarik wisata yang dapat mendukung pengembangan tanaman herbal tersebut. Kegiatan pengembangan tanaman herbal ini dapat memotivasi anggota KWT serta anggota Pokdarwis untuk memelihara lingkungannya atau pekarangan rumahnya masing-masing. Setiap pekarangan memiliki hubungan fungsional secara ekonomi, biofisik, dan ekologi dengan penghuninya (Dewi \& Widiyawati, 2019). Tujuan pelaksanaan kegiatan PPDM ini adalah agar Desa Catur di Kintamani Bali menjadi destinasi wisata yang unik yang mengandalkan keindahan alam, tanaman herbal, dan keunikan budaya. Dengan demikian, wisatawan domestik maupun mancanegara semakin sering mengunjungi desa ini, sehingga masyarakatnya mendapatkan peningkatan pengetahuan dan kesejahteraan.

\section{Metode Pelaksanaan}

Tempat dan Waktu. Kegiatan Program Pengembangan Desa Mitra (PPDM) dilaksanakan di Desa Catur, Kecamatan Kintamani, Kabupaten Bangli, Provinsi Bali selama 7 bulan mulai dari bulan Maret - September 2018. Tempat kegiatan PPDM berjarak $53 \mathrm{~km}$ dari Universitas Dhyana Pura (Undhira) Bali.

Khalayak Sasaran. Kegiatan PPDM ditawarkan pada Kelompok Wanita Tani (KWT) dan Kelompok Sadar Wisata (Pokdarwis) di Desa Catur. Jumlah peserta yang mengikuti kegiatan adalah 48 orang KWT dan 23 orang Pokdarwis.

Metode Pengabdian. Metode pelaksanaan kegiatan PPDM dilakukan dalam tiga tahapan yaitu tahap pelatihan, tahap pendampingan, dan tahap pemasaran destinasi wisata herbal. Anggota KWT dilatih dalam pengenalan jenis dan manfaat tanaman herbal, pembuatan produk herbal, dan penataan lingkungan agar bersih, sehingga wisatawan nyaman ketika mengujungi Desa Catur. Pelatihan kepada Pokdarwis tentang pengenalan jenis objek wisata, penataan kawasan desa, pembuatan jalur trekking, dan pengenalan bahasa Inggris. Kegiatan pelatihan KWT dan Pokdarwis ini dilaksanakan 2 kali seminggu selama 4 bulan. Setelah pelatihan dilakukan kepada anggota KWT dan Pokdarwis, maka tim memberikan pendampingan untuk melakukan secara mandiri setiap materi pelatihan. Pendampingan bertujuan untuk memberikan saran dan pengetahuan tambahan terhadap jenis kegiatan yang dilakukan secara mandiri tersebut. Setelah produk herbal dibuat serta kawasan wisata Catur ditata dengan baik, maka tim PPDM melatih dan mendampingi anggota KWT dan Pokdarwis memasarkan objek wisata herbal di media cetak, media sosial, TV, media online, dan sebagainya. Pelatihan, pendampingan, dan pemasaran ini bertujuan untuk memberikan pengetahuan kepada KWT dan Pokdarwis, sehingga Desa Catur menjadi objek wisata yang menarik bagi wisatawan. 
Indikator Keberhasilan. Kegiatan PPDM dikatakan cukup berhasil karena anggota KWT mengalami peningkatan pengetahuan dalam pengenalan jenis dan manfaat tanaman herbal, pembuatan produk herbal, dan penataan lingkungan yang bersih. Peningkatan pengetahuan ini sekitar $90 \%$ dari 43 orang anggota KWT setelah dilakukan pre test dan post test. Anggota KWT sudah berhasil membuat produk herbal. Keberhasilan peningkatan pengetahuan anggota Pokdarwis sekitar 90\% dari 22 orang setelah dilakukan pre test dan post test. Anggota Pokdarwis sudah mampu mengelola potensi wisata yang ada di Desa Catur serta membuat jalur trekking bagi wisatawan.

Metode Evaluasi. Evaluasi terhadap kehadiran anggota KWT dan Pokdarwis pada saat pelatihan, pendampingan, dan pemasaran destinasi wisata herbal. Setiap anggota KWT dan Pokdarwis dilihat peningkatan pengetahuannya setelah melaksanakan pre test, post test (Rifa'i, dkk., 2017, 2018; Kudsiah, dkk., 2018), membuat produk herbal, menata kawasan wisata, dan membuat jalur trekking di Desa Catur. Selanjutnya, anggota KWT dan Pokdarwis mampu mengajar kelompok masyarakat lain di Desa Catur tersebut.

\section{Hasil dan Pembahasan}

\section{A. Pengembangan Tanaman Herbal}

Masyarakat Desa Catur memiliki keinginan yang kuat agar hasil perkebunan dan keindahan alamnya dapat dikembangkan menjadi destinasi wisata. Kopi arabika merupakan tanaman yang tumbuh subur di Desa Catur. Tim pelaksana PPDM memberikan pelatihan kepada anggota Kelompok Wanita Tani (KWT) tentang pengenalan jenis tanaman herbal dan manfaatnya. Anggota KWT dilatih untuk mengenal jenis-jenis tanaman herbal di sekitarnya yaitu kopi, jeruk, jahe, kunyit, kumis kucing, sereh, dan sebagainya. Peranan kaum wanita merupakan salah satu modal dalam upaya pengembangan tanaman herbal (Dewi \& Widiyawati, 2019). Pengetahuan anggota KWT di Desa Catur terus mengalami peningkatan sebagaimana terlihat pada Gambar 1 berikut ini.

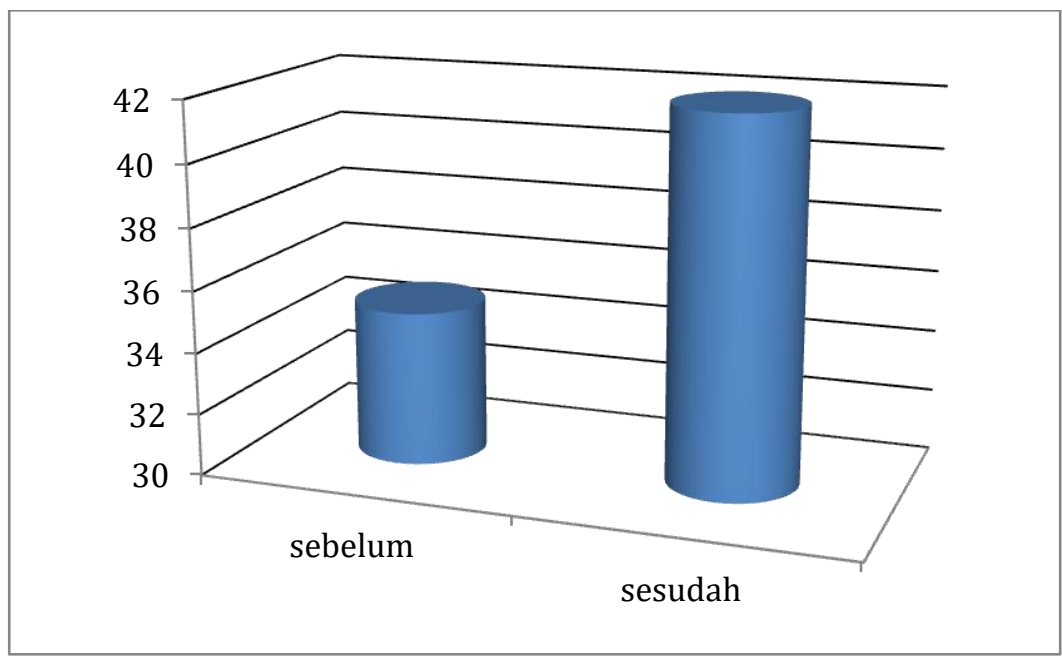

Gambar 1. Grafik Peningkatan Pengetahuan KWT

Peningkatan pengetahuan anggota KWT dalam pengembangan tanaman herbal pada Gambar 1 terlihat setelah diberikan pre test dan post test. Peningatakn ini sekitar 90\% dari 43 orang anggota KWT yang hadir pada saat pelatihan, pendampingan, dan pemasaran. Peningkatan pengetahuan ini berguna bagi masyarakat gar mengetahui jenis tanaman dan mengolahnya untuk membuat produk herbal. Tanaman herbal bermanfaat sebagai obat yang dapat menyembuhkan penyakit kulit, luka, gatal-gatal, flu, diare, kesehatan rambut, dan 
sebagainya. Dengan adanya tanaman herbal di sekitar rumah penduduk, maka masyarakat dapat mengurangi pengeluaran biaya pengobatan untuk kesembuhannya. Budidaya tanaman obat di pekarangan biasanya untuk konsumsi sendiri (Dewi \& Widiyawati, 2019). Dengan demikian, masyarakat tidak perlu mengkonsumsi obat yang berbahan dasar kimia ketika mengalami sakit. Selain itu, tanaman herbal bermanfaat untuk meningkatkan kualitas oksigen serta kesejukan di sekitar rumah penduduk tersebut.

Proses pengembangan tanaman herbal dilakukan dengan 3 tahap yaitu pelatihan, pendampingan, dan pemasaran. Tanaman herbal yang sudah siap dipanen yang diambil dari kebun induk maupun halaman rumah masyarakat, kemudian diolah menjadi produk herbal yaitu teh cerry kopi (cascara), teh daun kopi, dan parfum kopi. Proses pengembangan tanaman herbal dan pembuatan produk herbal di Desa Catur sebagaimana terlihat pada Gambar 2 berikut ini.
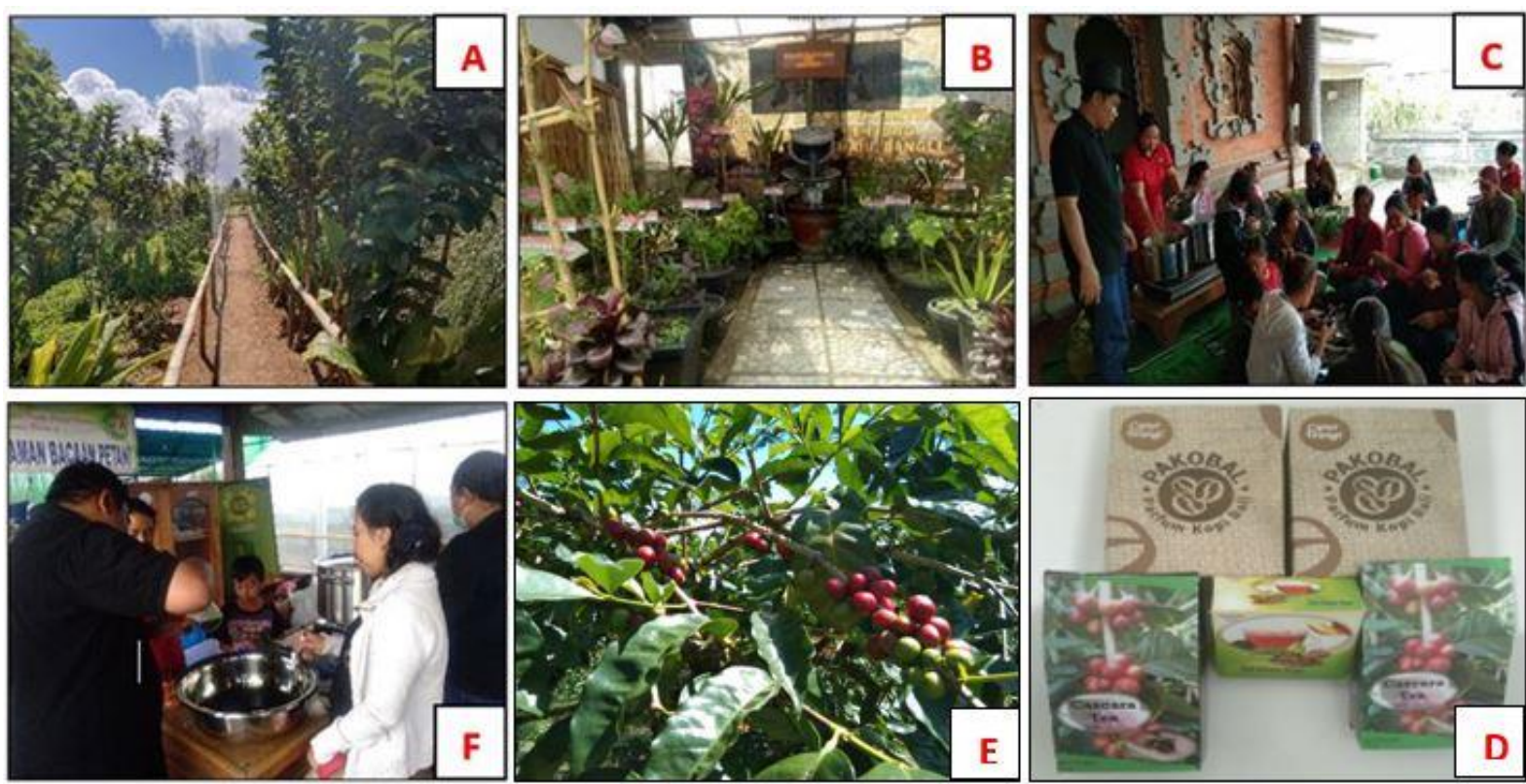

Gambar 2. Dokumentasi kegiatan yang dilakukan oleh KWT di Desa Catur, Kintamani, Bali: A) kebun induk tempat budidaya tanaman herbal; B) budidaya tanaman herbal di halaman rumah; C) pelatihan pengenalan jenis dan manfaat tanaman herbal; D) produk herbal yang sudah dikemas yaitu teh cerry kopi, teh daun kopi, dan parfum kopi; E) pembudidayaan kopi arabika yang termasuk tanaman herbal; dan F) proses pembuatan produk herbal.

Produk herbal yang sudah berhasil dikemas dan dipasarkan oleh anggota KWT yaitu teh cerry kopi, teh daun kopi, dan parfum kopi. Produk herbal ini berasal dari limbah kopi yaitu kulit dan daun kopi. Kopi merupakan tanaman herbal serta memiliki khasiat untuk kesehatan manusia yang terdapat pada daun, biji, dan buah, sehingga sekitar $80-90 \%$ kopi dikonsumsi oleh orang dewasa setiap hari (Prasetyono, 2018). Produk herbal lainnya yang dibudidayakan di Desa Catur adalah daun jinten. Daun jinten bermanfaat untuk menyembuhkan gangguan pernapasan, menjaga kesehatan kulit, mencegah kanker, menurunkan stress dan cemas, mengobati demam, mengatasi sindrom usus, mencegah sariawan, menjaga tekanan darah, dan sebagainya (Maressa, 2018).

Daun jinten dan kopi merupakan salah satu produk herbal yang bermanfaat bagi kesehatan manusia. Berbagai jenis makanan tradisional serta minuman yang mengandung khasiat herbal juga dikembangkan di Desa Catur seperti snack 
keladi, sate keladi, sayur undis, teh daun kopi, teh cascara, dan lain-lain. Pemanfaatan lahan pertanian atau perkebunan secara maksimal dapat mensejahterakan masyarakatnya (Sarifudin, dkk., 2019). Semakin banyak masyarakat mengembangkan potensi desanya termasuk pembudidayaan tanaman herbal, maka integrasi herbal dengan desa wisata akan menghasilkan keunikan tersendiri karena dapat memberikan selling point bagi masyarakat Desa Catur dan sekitarnya.

\section{B. Pengembangan desa wisata herbal}

Pengembangan potensi Desa Catur menjadi destinasi wisata herbal tidak terlepas dari pelatihan, pendampingan, dan pemasaran yang dilakukan oleh tim PPDM kepada anggota KWT dan Pokdarwis. Pengetahuan yang didapatkan oleh anggota Pokdarwis diterapkan dalam mengelolah kawasan wisata, pembuatan jalur trekking, dan pemasaran objek wisata. Pengetahuan Pokdarwis ini terus mengalami peningkatan yang dapat dilihat setelah dilaksanakan pre test dan post test sebagaimana terlihat pada Gambar 3 berikut ini.

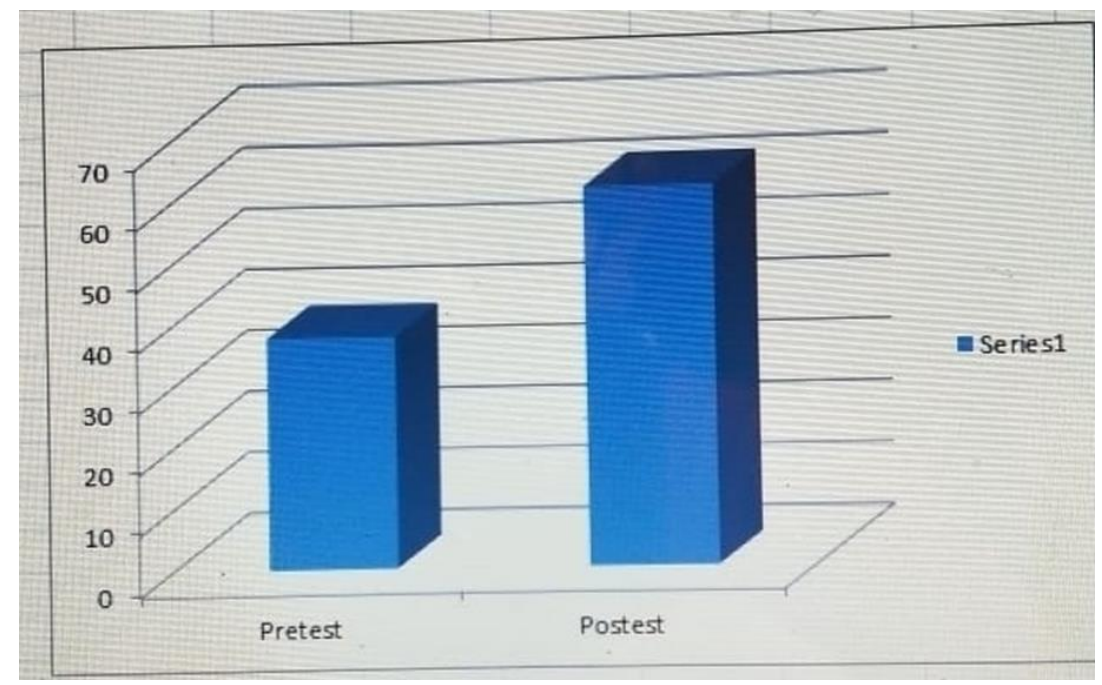

Gambar 3. Grafik Peningkatan Pengetahuan Pokdarwis

Keberhasilan peningkatan pengetahuan anggota Pokdarwis pada Gambar 3 sekitar $90 \%$ dari 22 orang yang mengikuti kegiatan pelatihan dan pendampingan. Jumlah ini diperoleh setelah dilaksanakan pre test dan post test selama kegiatan berlangsung. Anggota Pokdarwis sudah mampu mengelola potensi wisata yang ada di Desa Catur serta membuat jalur trekking bagi wisatawan. Desa ini menjadi destinasi wisata yang unik karena mengendalkan keindahan alam, produk herbal, dan budaya yang unik.

Pengembangan destinasi wisata herbal ini dilakukan oleh anggota Pokdarwis yang dibantu oleh tim PPDM. Setiap anggota Pokdarwis diberi pelatihan dan pendampingan guide, pembuatan jalur trekking, pengenalan produk herbal dalam bahasa Inggris, cara penyajian kuliner tradisional, spa herbal, dan pembuatan gazebo untuk tempat minum produk herbal. Hasil penataan kawasan ini membuat wisatawan domestik maupun mancanegara senang berkunjung ke Desa Wisata Herbal Catur. Pengembangan desa wisata herbal di desa ini sebagaimana terlihat pada Gambar 4.

Pelatihan dan pendampingan kepada anggota Pokdarwis bertujuan untuk menata lingkungannya agar menjadi daya tarik bagi wisatawan. Kerja keras dari anggota Pokdarwis serta masyarakat selama pelatihan dan pendampingan tim 

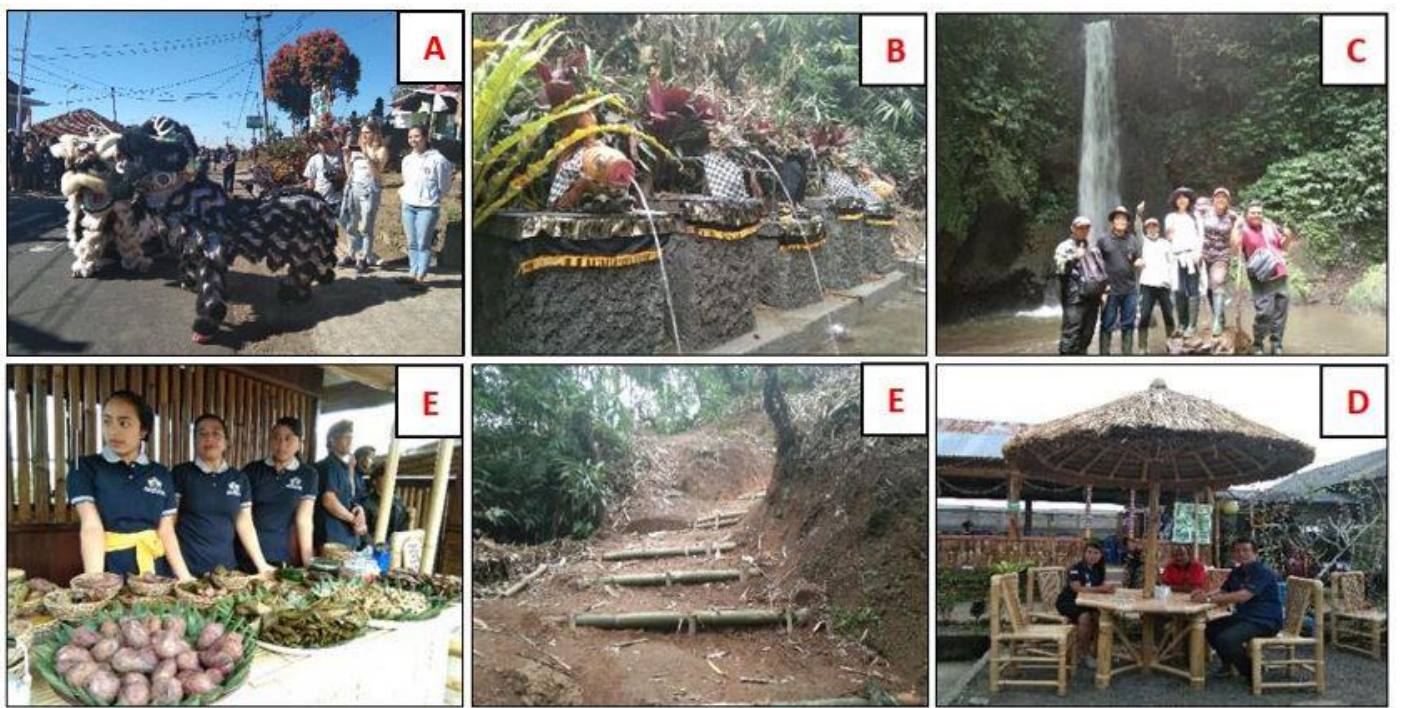

Gambar 4. Dokumentasi kegiatan yang dilakukan oleh Pokdarwis di Desa Catur, Kintamani, Bali: A) atraksi barongsai wujud akulturasi budaya Bali dan Tionghoa disaksikan oleh wisatawan; B) panataan objek wisata mata air suci (holy water); C)

penataan air terjun Tiying Seni; D) pembuatan gazebo bagi wisatawan; E) pembuatan jalur trekking di kebun kopi dan jeruk; dan F) pelatihan penyajian makanan dan minuman tradisional.

PPDM membuahkan hasil yang sangat membanggakan. Desa Wisata Herbal Catur diutus oleh pemerintah daerah untuk mewakili Kabupaten Bangli mengikuti lomba Tanaman Obat Keluarga (Toga) se-Provinsi Bali dan meraih juara 3. Kesuksesan ini terus berlanjut pada tanggal 10 Juni 2019 mengikuti lomba desa wisata se-Provinsi Bali yang diselenggarakan oleh Kementerian Pariwisata dan Kementerian Desa dan berhasil meraih juara 2. Kemudian tanggal 30 - 31 Agustus 2019 Desa Catur menjadi juara 3 dalam mengikuti event launching Go Destination Village (GODEVI) dan Pameran Desa Wisata yang diselenggarakan oleh Dinas Pariwisata Provinsi Bali yang bekerja sama dengan Kementerian Desa.

Prestasi yang diraih oleh Desa Wisata Herbal Catur merupakan kerja keras dari KWT dan Pokdarwis yang memberikan pelayanan yang baik kepada wisatawan. Setiap wisatawan yang datang ke Desa Catur akan menikmati keindahan alam, keunikan budaya, dan produk herbal yang berkhasiat bagi kesehatan. Pemanfaatan tanaman herbal bertujuan untuk meningkatkan kualitas kesehatan masyarakat. Pengetahuan tentang pola hidup sehat bertujuan untuk mencegah timbulnya berbagai penyakit (Wulandari, dkk., 2019). Pengembangan desa wisata merupakan salah satu strategi untuk mengedukasi masyarakat maupun wisatawan agar kembali membudidayakan tanaman herbal (back to nature) serta meningkatkan kesejahteraan masyarakat Desa Catur pada khususnya. Wisatawan dari Jerman dan Jepang pernah melakukan studi banding ke Desa Catur selama 3 hari tentang keunikan budaya serta budidaya tanaman herbal (UDP, 2017). Dengan adanya penataan kawasan wisata yang baik, maka Desa Catur menjadi tempat pengetahuan tanaman herbal dan sekaligus sebagai destinasi wisata berbasis herbal.

\section{Pemasaran destinasi wisata herbal}

Pengembangan potensi wisata herbal diperlukan pemasaran yang serius dari masyarakat. Pemanfaatan teknologi merupakan solusi dalam mempromosikan 
berbagai produk herbal serta keunikan kawasan wisata di Desa Catur. Oleh sebab itu, tim pelaksana PPDM memberikan pelatihan dan pendampingan kepada anggota Pokdarwis dan anggota KWT tentang pemasaran produk herbal melalui media sosial seperti televisi, youtube, facebook, whatsapp, instagram, dan berbagai media online maupun media cetak lainnya. Pemanfaatan teknologi merupakan cara yang efektif dalam meningkatkan kunjungan wisata, pembuatan produk, promosi, dan peningkatan kesejahteraan masyarakat Desa Catur pada khususnya serta masyarakat Indonesia pada umumnya.

Metode dan langkah-langkah pemasaran destinasi wisata herbal di Desa Catur yang dilakukan oleh anggota Pokdarwis dan KWT selama ini sebagaimana ditunjukkan pada Gambar 5 berikut ini.

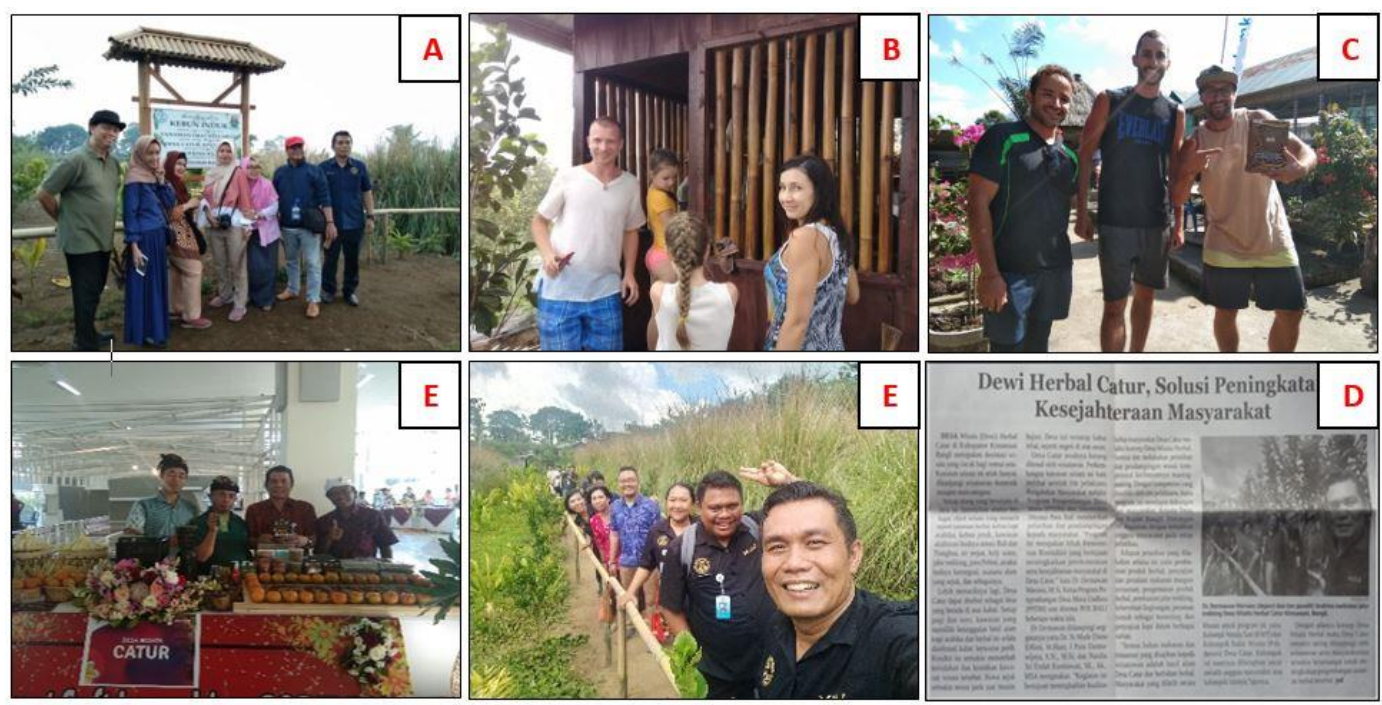

Gambar 5. Dokumentasi kegiatan yang dilakukan oleh Pokdarwis dan KWT di Desa Catur, Kintamani, Bali dalam mempromosikan desanya: A) peserta rakornas HKI

Kementerian Ristekdikti berwisata di kebun induk herbal; B) wisatawan mancanegara mengedukasi anaknya tentang manfaat herbal; C) wisatawan mancanegara mempromosikan kopi dan Desa Catur; D) mengikuti pameran Go Destination Village; E) wisatawan melakukan trekking di kebun kopi, jeruk, dan herbal; dan F) promosi di media cetak koran Pos Bali berjudul Dewi Herbal Catur.

Keunikan daya tarik wisata di Desa Catur telah dilengkapi dengan akomodasi dan atraksi budaya. Kerja sama yang terjalin antara anggota Pokdarwis, anggota KWT, dan tim pelaksana PPDM dari Universitas Dhyana Pura Bali, maka berhasil menyusun paket wisata herbal, alam, dan budaya yang dapat memanjakan setiap wisatawan yang berwisata ke Desa Catur. Paket wisata yang ditawarkan oleh Pokdarwis kepada wisatawan berdasarkan daya tarik wisata yang tersedia, antara lain:

1. Paket 1: Wisatawan disuguhkan minuman herbal seperti teh cascara, teh daun kopi, teh daun piduh, sereh, kopi, kudapan pangan lokal, dan lain-lain.

2. Paket 2: Wisatawan diberikan kelas pengenalan jenis dan manfaat tanaman herbal dalam bahasa Indonesia dan Inggris. Selain itu, pengenalan jenis-jenis tanaman herbal serta proses pembuatan produk herbal dapat dilihat melalui TV 36 inch yang diberikan oleh tim PPDM.

3. Paket 3: Wisatawan makan siang dengan menu pangan tradisional yang memiliki manfaat bagi kesehatan serta diambil dari kebun masyarakat. 
4. Paket 4: Wisatawan melakukan perjalanan wisata atau trekking ke air terjun, sumber mata air suci, dan kebun herbal. Pada saat trekking di kebun kopi dan jeruk, wisatawan dapat memetik kopi atau jeruk secara langsung dan gratis di jalur trekking tersebut.

5. Paket 5: Setelah pulang dari trekking, wisatawan diberikan pelayanan spa dan akupresur dengan menggunakan produk herbal dari KWT untuk memulihkan kondisi fisik wisatawan.

6. Paket 6: Akomodasi homestay telah tersedia sebanyak 8 homestay atau 24 kamar tidur dengan suasana pedesaan yang sejuk karena Desa Catur berada pada ketinggian 1.250 meter dari permukaan laut dan suhu sekitar $18-20$ derajat Celsius.

Paket wisata ini bertujuan untuk memberikan kepuasan dan sekaligus mengedukasi setiap wisatawan yang berwisata di Desa Catur tersebut. Paket wisata ini disesuaikan dengan usia serta keinginan wisatawan, agar setiap wisatawan dapat menikmati suasa alam dan keunikan budaya di desa ini sesuai seleranya masing-masing. Dengan demikian, paket wisata akan terus dikembangkan sesuai peningkatan kunjungan wisatawan tersebut.

\section{Keberhasilan Kegiatan}

Pelatihan dan pendampingan yang dilakukan oleh tim PPDM berdampak pada peningkatan pengetahuan dan keterampilan anggota KWT dalam mengelola hasil alamnya. Anggota KWT berhasil mengenal jenis dan manfaat tanaman herbal serta membuat produk herbal yaitu teh cerry kopi (cascara), teh daun kopi, dan parfum kopi. Teh cerry kopi (cascara) dan teh daun kopi merupakan limbah kopi yang biasanya dibuang. Dengan adanya pengetahuan yang dimiliki oleh anggota KWT maka berhasil membuat produk herbal dan mengemasnya, sehingga menarik minat wisatawan.

Keberhasilan anggota Pokdarwis terlihat pada peningkatan pengetahuan dan keterampilan dalam menata kawasan Desa Catur menjadi destinasi wisata yang dikunjungi oleh wisatawan. Wisatawan yang berwisata ke Desa Catur berasal dari berbagai daerah di Indonesia maupun luar negeri. Wisatawan mancanegara yang pernah mengungjungi desa ini berasal dari Jepang, Australia, Jerman, Thailand, Belanda, Malaysia, Inggris, dan Korea. Setiap wisatawan yang berkunjung ke Catur memiliki tujuan yang berbeda-beda. Ada yang ingin belajar dan melihat secara langsung budidaya tanaman herbal, proses pembuatan produk herbal, berbagai jenis makanan dan minuman herbal, keindahan alam, budaya, dan sebagainya. Dengan adanya paket-paket wisata ini, maka wisatawan menikmati manfaat ganda yaitu beriwisata dengan suasana alam pedesaaan, mendapat pengetahuan tentang tanaman herbal, serta meningkatnya kesehatan wisatawan tersebut.

\section{Kesimpulan}

Pelatihan dan pendampingan yang dilakukan oleh tim PPDM kepada anggota KWT dan Pokdarwis berdampak positif dalam peningkatan pengetahuan serta keterampilan dalam pengembangan Desa Wisata Herbal Catur Kintamani Bali. Desa Catur menjadi salah satu destinasi wisata yang menarik bagi wisatawan karena adanya keindahan alam, produk herbal, dan keunikan budaya masyarakatnya. Keunikan desa wisata herbal ini semakin dikenal oleh masyarakat maupun wisatawan karena dipasarkan melalui media sosial atau internet.

\section{Ucapan Terima Kasih}

Penulis mengucapkan terima kasih kepada Direktorat Riset dan Pengabdian Masyarakat, Direktorat Jenderal Penguatan Riset dan Pengembangan, Kementerian 
Riset, Teknologi, dan Pendidikan Tinggi atas hibah PPDM pendanaan tahun 2019. Ucapan terima kasih kepada Rektor dan Lembaga Penelitian dan Pengabdian Masyarakat (LPPM) Universitas Dhyana Pura Bali yang telah membantu kegiatan pengabdian masyarakat selama ini, sehingga tim PPDM mampu melaksanakan tri dharma perguruan tinggi dengan baik.

\section{Referensi}

Arnawa, I.K., Ruma, I.W., Astuti, P.S., Palgunadi, P., Raka, I.D.N., Martini, L.K.B. (2014). Mengenal potensi Kawasan Agropolitan Desa Catur Kecamatan Kintamani Kabupaten Bangli, Bali. Majalah Aplikasi Ipteks Ngayah: 5 (1), 37-45.

Bangli, D.P. \& KK (2018). Potensi Desa Catur Kintamani, Bangli. http://disparbud.banglikab.go.id, http://disparbud.banglikab.go.id/index.php /baca-berita/1052/Potensi-Desa-Catur-Kintamani-Bangli.html (Diakses, 26 Juli 2019).

Bangli BPSK. (2017). Kecamatan Kintamani dalam angka. banglikab.bps.go.id, https:// banglikab.bps.go.id/publication/2017/09/20/f1cc4c8f225fb9721d03 cad8/kecamatan-kintamani-dalam-angka-2017.html (Diakses, 23 Juli 2019).

Dewi, P.S., \& Widiyawati, I. (2019). Penerapan teknologi budidaya tanaman obat sebagai upaya pemanfaatan lahan pekarangan di Kelurahan Pabuwaran, Purwokerto, Jawa Tengah. Jurnal Panrita Abdi, 3(2), 105 - 112.

Desa Catur. (2011). Profil Desa Catur. blogspot.com, http://desacatur.blogspot.com/2011/02/profil-desa-catur.html (diakses, 5 April 2019)

Maressa. (2018). Manfaat Daun Jinten Untuk Kulit dan Penyakit. https://manfaat.co.id, https://manfaat.co.id/manfaat-daun-jinten (Diakses, 2 Agustus 2019).

Prasetyono, A.P. (2018). Ketika Kopi Mengalahkan Herbal. https://ristekdikti.go.id, https://ristekdikti.go.id/ketika-kopi-mengalahkan-herbal/ (Diakses, 6 Mei 2019).

Sarifudin, Aldino, S., Fachry, M., Alqaroni, M., \& Nur'ihsani, A.S. (2019). EDPERDAY (Edukasi Pertanian Swadaya): Upaya Pemberdayaan Pemuda Pertanian dalam Lahan Edukasi Sayur Organik. Jurnal Pengabdian kepada Masyarakat (Indonesian Journal of Community Engagement), 5(2), 304 - 317.

UDP. (2017). Undhira Mengabdi di Catur Kintamani Kembangkan Desa Herbal dan Desa Wisata. web.facebook.com, https://web.facebook.com/photo.php?fbid= $1128844443882370 \&$ set $=$ pcb. $1128851027215045 \&$ type $=3 \&$ theater\&_rdc $=1 \&_{\text {_ }}$ rdr (diakses, 3 Juni 2019).

Wulandari, C., Setiyarini, D.W., Bariroh, K., Laraswati, Azhari, M.F., \& Aziz, R.A.I. (2019). Upaya Peningkatan Status Kesehatan Kelompok Rentan dengan Pendekatan Pembelajaran dan Pemberdayaan Masyarakat. Jurnal Pengabdian kepada Masyarakat (Indonesian Journal of Community Engagement), 5(2), 167 $-187$.

Penulis:

Dermawan Waruwu, Program Studi Psikologi, Fakultas Ilmu Kesehatan, Sains, dan Teknologi, Universitas Dhyana Pura, Provinsi Bali. E-mail: dermawanwaruwu@undhirabali.ac.id

Ni Made Diana Erfiani, Program Studi Sastra Inggris, Fakultas Ekonomika dan Humaniora, Universitas Dhyana Pura, Provinsi Bali. E-mail: dianaerfiani@undhirabali.ac.id

I Putu Darmawijaya, Program Studi Fisioterapi, Fakultas Ilmu Kesehatan, Sains, dan Teknologi, Universitas Dhyana Pura, Provinsi Bali. E-mail: darmawijaya@undhirabali.ac.id

Natalia Sri Endah Kurniawati, Program Studi Manajemen Pemasaran, Fakultas Ekonomika dan Humaniora, Universitas Dhyana Pura, Provinsi Bali. E-mail: nataliasriendah@undhirabali.ac.id

Bagaimana men-sitasi artikel ini:

Waruwu, D., Erfiani, N.M.D., Darmawijaya, I.P., \& Kurniawati, N.S.E. (2020). Pengembangan

Tanaman Herbal Sebagai Destinasi Wisata di Desa Catur, Kintamani, Bangli, Provinsi Bali. Jurnal Panrita Abdi, 4(1), 1 - 10. 